\title{
COMMENT
}

\section{THE USE OF APPRAISALS IN SEC DOCUMENTS}

Both the Securities Act of $1933^{1}$ and the Securities Exchange Act of $1934^{2}$ give the Securities and Exchange Commission control over the use of appraisals in documents filed pursuant to those Acts. ${ }^{3}$ Although there are no SEC regulations expressly prohibiting or restricting their use, ${ }^{4}$ the Commission and its staff have long adhered to the position that assets (other than marketable securities), recorded on balance sheets contained in documents filed under both Acts, must be carried at historical cost less depreciation. ${ }^{5}$ Not only has this nowriteup policy been consistently enforced in relation to financial statements, but the Commission staff has also resisted attempts at supplemental disclosure of appraised asset values which exceed historical $\operatorname{cost}^{6}$ in the narrative portions of 1933 and 1934. Act documents. ${ }^{7}$

Recent changes in the policy of the SEC relating to projections, ${ }^{8}$ coupled with advances in the standards of the appraisal industry, indicate that the time is ripe for a reexamination of the Commission's longstanding policy of discouraging the use of appraisal results. Specifically, awareness has grown among members of the financial and legal communities that financial disclosures in SEC documents which are restricted to income

${ }^{1} 15$ U.S.C. $\S \S 77 \mathrm{a}-77 \mathrm{aa}(1970)$.

${ }^{2}$ Id. $\$ \$ 78 \mathrm{a}-78 \mathrm{o}, 78 \mathrm{o}-3,78 \mathrm{p}-78 \mathrm{hh}(1970)$.

${ }^{3}$ Securities Act of $1933 \S 19(a), 15$ U.S.C $\S 77 \mathrm{~s}$ (1970); Securities Exchange Act of $1934 \oint 13(\mathrm{~b}), 15$ U.S.C. $\S 78 \mathrm{~m}(1970)$.

${ }^{4}$ See H. Sowards, 11 Business Organizations, The Federal Securities ACt $\S 8.01$ [3][a] (1965).

5 See H. Kellogg \& M. Poloway, Accountants SEC Practice Manual 94303 (1971); L. RAPPAPORT, SEC ACOOUNTING PRACTICE AND PROCEDURE 3.27-.32 (3d ed. 1972); H. SOWARDS, supra note 4, § 8.01 [3]; Manne, Accounting and Administrative Law A spects of Gerstle v. Gamble-Skogmo, Inc., 15 N.Y.L.F. 304, 314-19 (1969).

${ }^{6}$ See H. KellogG \& M POLOWAY, supra note 5, If 4303; Manne, supra note 5, at 314-15.

The Commission does require that estimates be made of mineral and resource reserves in extractive industries, but the estimates are not assigned monetary values. See SEC Form S-1, Item 10, Instruction 2, 1 OCH FED. SEC. L REP. If 7123; SEC Form S-3, Item 4, 1 CCH FED. SEC. L. REP. I 7153; SEC Form S-10, Items 18-19, 1 CCH FED. SEC. L. REP. I 7219.

${ }^{7}$ E.g., SEC Form S-1, I CCH FED. Sec. L. ReP. I $97121-29$; Exchange Act Schedule 14A, 17 C.F.R. $\$ 240.14$ a-101 (1973).

${ }^{8}$ See SEC Securities Act Release No. 5362, SEC Exchange Act Release No. 9984 (Feb. 2, 1973), in [1972-1973 Transfer Binder] CCH FED. SEC. L. REP. I 79,211 (Commission will now permit issuers, who meet certains standards, to make economic forecasts in filed documents subject to filing and disclosure rules to be promulgated by the Commission). 
figures and historical cost data may be used to deceive and defraud innocent investors, ${ }^{9}$ and that in many cases they do not, in an inflationary economy, even provide sufficient information to enable an investor to make informed investment decisions. ${ }^{10}$ Second, the growing sophistication of the appraisal profession suggests that many of the justifications for the prejudices formed by the SEC in the 1930's against the disclosure of appraisal data are no longer valid. ${ }^{11}$

This Comment will examine the SEC's position on the use of appraisal data in required disclosure documents, and will study those areas where pressure for a change in SEC policy has been most apparent. The present-day capacity of the appraisal profession to deal with problems in those areas will then be scrutinized. Finally, an attempt will be made to reconcile conflicting policy considerations, and limited regulations will be proposed as a first step toward allowing the use of appraisals in SEC documents.

\section{WHAT IS AN APPRAISAL?}

Any determination of the reliability of appraisal reports and the appropriateness of their use in SEC documents requires a preliminary understanding of appraisal methods and procedures. Two recognized methods for determining the value of a property produce data of particular significance'to SEC filings. These are the comparable sales or market value approach, and the income approach. ${ }^{12}$ Each of these methods of arriving at the value of a property involves judgment and requires assumptions regarding future market trends. ${ }^{13}$ For example, the market value approach is based on the fundamental assumption that, if other properties have sold at a certain price, then the subject property will sell at the same or a comparable price. ${ }^{14}$ The income

\footnotetext{
${ }^{9}$ See text accompanying notes $38-42$ infra.

${ }^{10} \mathrm{See} \mathrm{H}$. SowARDS, supra note 4, $\$ 8.01$ [3]; Manne, supra note 5, at 314-19.

II See notes 54-82 infra \& accompanying text.

${ }^{12}$ See Principles of Appraisal Practice and Code of Ethics of the American Society of appraisers, in AMERICAN SOCETY of APPRAISERS, Professional APPRAISAL Services DIRECTORY - 1973, at 7 [hereinafter cited as ASA Principles]; Standards of Professional Practice, in Society of Real Estate APPRAISERS, INTERNATIONAL By-LAWS ANDSTANDARDS Of Professional Practice AND CONDUCT 10-11 (1972) thereinafter cited as SREA BY-LAWS \& Standards]. See also H. Baboock, ApPraisal Principles and Procedures 3 (1968).

A third method, the replacement cost approach, is used primarily in the insurance industry to determine, for example, the amount of property insurance to carry, the amount of the claim in an insured loss, or the allocation of the appropriate portion of the actual cost of a whole property to depreciating or wasting property components for cost recovery accounting and income tax deductions. See id. 178. It thus has little relevance to the subject matter of this Comment and will not be considered further.

${ }^{13}$ See $1 \mathrm{~J}$. BONBRIGHT, THE VALUATION OF PROPERTY 132-34 (1937).

${ }^{14}$ See $\mathrm{H}$. BABCOCK, supra note 12 , at 117 . The validity of such' an assumption of
} 
approach, on the other hand, used to determine the value of a company as a going concern, ${ }^{15}$ is based upon a capitalization of future earnings, requiring estimates of the size of the market for a company's products, sales volume forecasts and earnings forecasts. ${ }^{16}$

The selection of the proper method or methods to be followed in arriving at a valuation is the responsibility of the appraiser and is the most important decision in the appraisal process. ${ }^{17}$ The choice of method, in turn, is based upon a client's contemplated use of a property. An example illustrates the importance of this initial step, and also serves to justify what might otherwise appear to be an artificial restriction on the scope of the following material.

Should an appraiser be asked to place a value upon the investment in a business to be operated as a going concern, his method of analysis will differ radically from the situation in which a client contemplates the sale of a property. In the former case, the appraiser's valuation, in accordance with the income approach, would be based primarily upon a capitalization of the business' projected earnings. ${ }^{18}$ In making such a valuation, the appraiser would in fact be performing an earnings projection function similar to that of a securities analyst or a corporate executive.

On the other hand, when a client indicates that sale of a property is contemplated, the appraiser's use of the market valuation or comparable sales approach adds a new dimension to the procedure. An exception to the general principle that "a business is worth what it can earn" occurs when a sale of separate assets is planned. ${ }^{19}$ In those circumstances, the appraiser's ability to estimate the market value of assets, based upon his knowledge of relevant markets and his ability to evaluate the condition of an. asset, constitutes his most valuable skill.

course depends upon the continuation of both the "market" from which comparable sales data were obtained and the trends demonstrated in that market. See id.

${ }^{15}$ See $1 \mathrm{~J}$. BONBRIGHT, supra note 13 , at 233-39.

${ }^{16}$ See H. BABOOCK, supra note 12, at 192; cf. SREA BY-LAws \& STANDARDS, supra note 12 , at 11 .

${ }^{17}$ See ASA Principles, supra note 12, at 9, 12; Interview with George D. Sinclair, International Vice President, American Society of Appraisers, in Philadelphia, Pennsylvania, Nov. 15, 1972 [hereinafter cited as Sinclair Interview]. Many of the general appraisal procedures set forth in the text are an interpretation of discussions with Mr. Sinclair concerning methods of practice in the field of machinery and equipment appraisal. Conclusions about the appraiser's contribution using various methods of valuation are those of the author and should not be attributed to $\mathrm{Mr}$. Sinclair.

A combination of two or more valuation approaches may be proper in a given case.

See H. BABCOCK, supra note 12 , at 3.

${ }_{18}^{18}$ See $1 \mathrm{~J}$. Bonbrught, supra note 13 , at 233-39.

${ }^{19} \mathrm{Cf}$. note 8 supra. 
With these two types of appraisal in mind, it is submitted that the valuation of going concerns should be left in the hands of those persons, such as securities analysts and corporate executives, who possess demonstrated and well-recognized qualifications to make broad-ranging determinations relating to a particular company's projected earnings. To permit appraisal valuations based upon the income capitalization method to be included in documents filed with the SEC would appear to offer the investor little in the way of knowledge which could not be derived from more familiar sources, ${ }^{20}$ while creating a real danger that a valuation derived from earnings projections but labeled an appraisal might be erroneously viewed as "hard" fact.

This Comment will recommend only the inclusion of market value appraisals in SEC documents, and will limit its discussion to situations appropriate to that approach. The possibility that a particular property may have more than one value depending upon its contemplated use suggests that, in any use of appraisal values in SEC documents, either the market to which a stated valuation pertains ought to be disclosed in the filed document or a rule should be in effect requiring that all appraisal figures relate to a particular standardized range of asset markets and contemplated uses. A limitation by rule on the use of appraisals in SEC documents to situations in which the sale of assets is contemplated, requiring full disclosure of the type of market in which such a sale is envisioned, would serve not only to assure that an investor is properly informed as to the basis of an appraisal and that a satisfactory degree of uniformity is attained, but also may provide a means by which the appraisals disseminated through SEC-related reports could be limited to those types in which the contributions of the appraisal profession to investor knowledge are potentially most significant.

Assuming, then, that a sale of assets is contemplated and appraisal at market value is appropriate, the appraiser still requires more information as to the type of sale planned by his client. Differing valuations, reflecting the different markets in which a property may be sold, will be reached depending upon whether a plant is to be sold piecemeal or as a going concern, whether equipment will be sold for use onsite or dismantled and sold in the used equipment or scrap market, and whether the client is willing or able to await an orderly sale or must sell in the forced liquidation market. Given the fact that a property may have two, three or even more market values (scrap, liquidation, wholesale, retail, etc.), it is essential that the appraiser select and 
specify the market in which the reported value obtains in order to avoid any misunderstanding or ambiguity. ${ }^{21}$

The practical elements which form the basis of an appraisal where a sale of assets is contemplated include the appraiser's physical inspection of the assets to determine their useful life and the markets in which they might be sold, research relating to the proper market or markets for such assets, and a further determination, utilizing both comparative sales and income techniques, of the predicted value of such assets in the selected markets. The method or methods upon which a determination of value is based, a description of the assets evaluated, factual assumptions underlying the valuation, and the valuation itself are set forth in the appraisal report. ${ }^{22}$

\section{HISTORICAL BASIS OF SEC APPRAISAL POLICY}

Three rationales have been advanced in support of the SEC's policy of near-total exclusion of appraisal reports from disclosure documents. It is claimed that historical cost data as a basis for valuation of fixed assets provides a comparatively objective and uniform method of valuation, that the exclusion of asset writeups is consistent with generally accepted accounting principles, and that practical difficulties in the accurate disclosure of the current value of assets would be insurmountable. ${ }^{23}$ The first two arguments probably do provide adequate justification for the policy of refusing to permit balance sheet figures to be adjusted on the basis of appraisal input. ${ }^{24}$ Neither, however, supports the additional restriction forbidding the disclosure of appraised asset values, in the narrative portion of disclosure documents, as a supplement to the conventional balance sheet.

The policy of excluding appraisal information from the narrative portion of filed documents must, therefore, be based upon the Commission's perception of practical difficulties inherent in its use. That this is a primary barrier preventing the inclusion of such information has been explicitly acknowledged by the SEC:

The Commission and its staff have traditionally looked with suspicion upon the inclusion of asset

${ }^{21}$ See id. 136-37.

${ }^{22}$ See ASA Principles, supra note 12, at 17-18.

Such reports are required to be filed as exhibits to SEC documents where use of appraisal information is permitted. See, e.g., SEC Form S-1, item 10, Instruction 2, 1 OCH FED. SEC. L. REP. $\$ 7123$ (requiring estimates of mineral and resource reserves held by registrants engaged in extractive industries).

${ }^{23}$ See H. SowARDS, supra note $4, \S 8.01$ [3] [b].

${ }^{24}$ But cf. note 35 infra. 
appraisals even in the text or narrative portion of proxy statements. It has been our experience that such appraisals are often unfounded or unreliable. For this reason, the Commission's staff, on a case-by-case basis, has usually requested the deletion of appraisals that have been included in proxy statements.

A study of some of the earliest cases before the Commission under the 1933 Act reveals a primary source of this broad administrative suspicion of appraised values. In Haddam Distillers Corp., ${ }^{26}$ a 1934 decision, the issuance of a stop order was based upon a finding that an appraisal, from which a 1933 Act registrant had derived fixed asset values used in a registration statement balance sheet, contained untrue statements of material fact: "Not only was the appraisal inexcusably careless, but the testimony impels toward the view that there was a dishonest attempt to inflate values beyond any maximum that differences of opinion might condone."27

In Breeze Corps., ${ }^{28}$ a 1938 decision, the Commission leveled another caustic attack against the quality of filed appraisal data:

Cousins was not a qualified appraiser. His valuation was not based upon independent investigation. His only information as to future prospects and as to costs was the estimates given him by the company and its executives. His valuation was not based upon a consideration of all relevant data which could, or should, have been available. ... In sum, the valuation, based upon methods which without question were incompetent and arbitrary, was not an appraisal. Clearly misleading, therefore, was a representation in the registrant's financial statements, based on this "appraisal," that in 1933 there had been an appreciation of $\$ 1,708,620.68$ in the value of registrant's intangibles. $^{20}$

In spite of such flagrant misuse of appraisal valuations, the

${ }^{25}$ Brief for SEC as Amicus Curiae at 24, Gerstle v. Gamble-Skogmo, Inc, 298 F. Supp. 66 (E.D.N.Y. 1969), affd in part \& rev'd in part, 478 F.2d 1281 (2d Cir. 1973) [hereinafter cited as SEC Brief].

${ }^{26} 1$ S.E.C. 37 (1934).

${ }^{27} I d$. at 46 .

The misrepresentation of asset values in the appraiser's report was particularly flagrant in this case. The report purported to give both "replacement cost new" and "sound value" for machinery located in the plant. Aside from the problem whether this was a proper appraisal method under the circumstances, see notes 17-22 supra \& accompanying text, it is apparent from the Commission's opinion that the values given in the report bore no relation to the cost of the equipment. For example, a used electric motor was listed at $\$ 400$ although it sold for $\$ 230$ in 1934 , and a motor truck was listed at $\$ 1,000$ although it sold for $\$ 716$ in 1930 and $\$ 133.75$ in 1934 . 1 S.E.C. at 45-46 (1934).

283 S.E.C. 709 (1938).

${ }^{29}$ Id. at 719 . 
Commission abstained from a blanket prohibition against the use of appraisal information in filed documents. ${ }^{30}$

No SEC case since the mid-1940's has dealt with the quality of appraisals. This is a clear indication of the staff's success in imposing upon registrants its policy, emanating from experience with appraisals in cases such as Haddam and Breeze, ${ }^{31}$ that all appraisal information should be excluded from filed documents. Thus the present policy of exclusion resulted not from a rule of absolute prohibition promulgated by the SEC, but from the adverse experience of the Commission's staff in dealing with the attempted use of appraisals by registrants in the 1930's and the early 1940's.

\section{PRESSURES FOR CHANGE}

Two compelling factors call for a reevaluation of present SEC appraisal policy. First, the near-blanket prohibition of disclosure of appraisal data has recently been criticized by both courts $^{32}$ and commentators. ${ }^{33}$ Criticism stems from the fundamental inconsistency between that policy and a basic tenet of the Commission's antifraud rules ${ }^{34}$ - that nondisclosure of relevant information may cause a document to be materially false or misleading ${ }^{35}$-and from the recognition that excluding appraisal data deprives investors of valuable investment information. ${ }^{36}$

${ }^{30}$ The Commission's apparent acceptance of the use of properly performed appraisals at that time (1938) is demonstrated by its handling of the Breeze situation. Rather than reject the balance sheet figures because they were arrived at by appraisal, the Commission tested them against previously developed standards meant to prevent misleading appraisals. See id. at 717.

${ }^{31}$ Oher early cases in which the SEC encountered defective or misleading appraisals include Associated Gas \& Elec. Co., 11 S.E.C. 975 (1942); Winnebago Distilling Co., 6 S.E.C. 926 (1940); Mining \& Development Corp., 1 S.E.C 786 (1936); Great Dike Gold Mines, Inc., 1 S.E.C. 621 (1936); Continental Distillers \& Importers Corp., 1 S.E.C. 54 (1935). See also SECAccounting Series Release No. 8 (May 20, 1938), in 4 CCH FED. SEC. L. REP. I 72,009.

${ }^{32}$ Cf. text accompanying notes $42-46$ infra. But cf. Sunray DX Oil Co. v. Helmerich \& Payne, Inc., 398 F.2d 447, 451-52 (10th Cir. 1968), (adopting the SEC's position that only "proved" oil reserves need be disclosed in a merger proxy statement, and holding that the omission of information concerning a major oil discovery on a tract of land adjacent to that owned by the acquired company was therefore not materially
misleading).

${ }^{33}$ See Kripke, The SEC, The Accountants, Some Myths and Some Realities, 45 N.Y.U.L. REV. 1151, 1188-97 (1970); Schneider, Nits, Grits, and Soft Information in SEC Fitings, 121 U. PA. L. REv. 254, 283 (1972). (1973).

${ }^{34}$ See, e.g., SEC Exchange Act Rules 10b-5, 14a-9, 17 C.F.R. $\S \S 240.10 \mathrm{~b}-5,240.14 \mathrm{a}-9$

${ }^{35}$ It has even been suggested that the pressure for full disclosure exerted by rule $10 \mathrm{~b}-5$ will force the SEC to abandon its traditional requirement of cost-basis accounting in all SEC filings. See Kripke, supra note 33, at 1192.

36 "In fact the SEC's position has generally gone beyond merely prohibiting writeups on the balance sheet in their seeming effort to prevent shareholders from learning helpful financial information." Manne, supra note 5 , at 315 . 
Second, because the conditions prevailing in the 1930's, resulting in the types of abuse encountered in Haddam and Breeze, are no longer prevalent in qualified segments of the appraisal profession, ${ }^{37}$ it is now appropriate for the SEC to take a second look at the potential contribution of appraisals to the task of providing the investor with relevant, reliable investment information.

\section{A. The Need for Disclosure}

The leading case illustrating the conflict between the Commission's appraisal prohibition and federal antifraud rules is Gerstle v. Gamble-Skogmo, Inc. ${ }^{38}$ a class action by former minority stockholders of an acquired corporation, General Outdoor Advertising Co., Inc., against Gamble-Skogmo, Inc., the acquiring corporation in a merger subject to the federal proxy rules. ${ }^{39}$ As characterized by the district court, the thrust of the plaintiffs' complaint was:

Skogmo failed in the (merger) proxy statement to disclose the true value of General's outdoor advertising plants and its intention to sell those assets immediately after the merger at an expected profit of approximately $\$ 15,000,000$, thus depriving the General stockholders of an undiluted interest in such capital gains realized on the sale of the General assets within nine months after the merger. ${ }^{40}$

The district court found that at the time the proxy statements were distributed to General's stockholders, Skogmo's management had knowledge of offers to purchase General's plants, had in-house appraisal reports which revealed that the market value of General's plants was greatly in excess of book value as stated in the balance sheet accompanying the proxy statement, and had an undisclosed intent to sell the General plants immediately after the merger. ${ }^{41}$ The court then held that it had been Skogmo's duty to insert in the textual portion of the proxy statement the appraised values of General's outdoor advertising plants and to disclose specifically its intent to sell those assets immediately after the merger; and that the failure to fulfill these duties constituted an omission of material information from the proxy statement in violation of rules $14 \mathrm{a}-9$ and $10 \mathrm{~b}-5 .{ }^{42}$

1969).
${ }_{31}{ }_{17}$ C.F.R. $§ \S 240.14 \mathrm{a}-1$ to -103 (1973).

${ }^{37}$ See notes 54-82 infra \& accompanying text.

$40298 \mathrm{~F}$. Supp. at 74.

${ }^{41} \mathrm{Id}$. at 103 . In the 9 -month period immediately following the merger, 12 plants with aggregate book value of $\$ 10,576,418$ were sold for a total of $\$ 25,081,121$. Id. at 87 .

${ }^{42} I d$ at 104. 
Skogmo raised the SEC appraisal prohibitions as a defense to the alleged antifraud violations. ${ }^{43}$ As a result, the district court asked the Commission to submit an amicus curiae brief to clarify its policy relating to the disclosure of appraisal results. While adhering to the position that fixed assets should be carried at historical cost less depreciation in all filed financial statements (absent an express exception by statute, rule or specific Commission authorization), the SEC brief stated the following exception to the policy against the inclusion of appraisals in the narrative or textual portion of proxy statements:

When a balance sheet in a proxy statement for a merger reflects assets at an amount that is substantially lower than their current liquidating value, and liquidation of those assets is intended or can reasonably be anticipated, the textual or narrative portion of the proxy statement must contain whatever available material information about their current liquidating value is necessary to make the proxy statement not misleading. ${ }^{44}$

Going on to deal specifically with the materiality of appraisals, the brief concluded:

$[\mathrm{I}] \mathrm{t}$ is the Commission's position that existing asset appraisals of current liquidating value must be disclosed in the textual or narrative portion of a proxy statement if they are made by qualified experts, they have a sufficient basis in fact and their omission would render the proxy statement materially misleading. ${ }^{45}$

The district court adopted this exception to the SEC's previous policy of exclusion and held that the staff's advice to General could not be successfully raised as a defense, relying in part upon its finding that the SEC was not informed of Skogmo's intent to liquidate General's assets. ${ }^{46}$

The Second Circuit affirmed the district court's finding of liability, solely on the ground that the merger proxy statement

${ }^{43} \mathrm{~A}$ member of the SEC staff, in discussing the possibility of disclosing the fair market value of certain of General's assets at a conference between General's management and SEC staff members held prior to shareholder voting, stated " 6 ... that it was contrary to the SEC policy to have that kind of prospective information' in a proxy statement." SEC Brief, supra note 25 , at 7-8.

${ }^{44}$ Id. at 19.

${ }^{45} I d$ at 25 .

${ }^{46} 298$ F. Supp. at 101.

On appeal Judge Friendly specifically rejected this finding:

The most that could be found was that Skogmo intended vigorously to pursue the program of sales if adequate prices could be secured and that it had good reason to expect they could be. We are confident that the SEC staff would not have allowed the appraisals to appear in the Proxy Statement even if this intention had been disclosed to it. 
failed to disclose adequately Skogmo's intention to pursue aggressively the policy of selling General's remaining plants upon completion of the merger. ${ }^{47}$ More important for our purposes was Judge Friendly's studied refusal to adopt the SEC's suggested exception to its policy against the inclusion of appraisals in the narrative portion of proxy statements. Recognizing that "[i] $t$ has long been an article of faith among lawyers specializing in the securities field that appraisals of assets could not be included in a proxy statement,"48 Judge Friendly concluded that the court

would be loathe to impose a huge liability on Skogmo on the basis of what we regard as a substantial modification, if not reversal of the SEC's position on disclosure of appraisals in proxy statements, by way of its amicus brief in this case. Indeed, it was to protect against this that Congress enacted section 23(a) of the Securities Exchange Act, 15 U.S.C. § 78w, which provides that 'No provision of this chapter imposing any liability shall apply to any act done or omitted in good faith in conformity with any rule or regulation of the Commission,' notwithstanding any later amendment. $^{49}$

What then is the status of the SEC's suggested exception to the "no appraisal" rule as voiced in the Commission's brief and approved by the district court? Judge Friendly clearly did not condemn the exception on its merits. On the other hand, that part of the opinion quoted above clearly suggests that the "no appraisal" standard, through constant application over the years, has achieved the status of a rule or regulation which can only be altered by a formal rule or Commission policy statement. ${ }^{50}$ In the absence of such a rule or statement, it is not clear that corporations deciding whether to include appraisal data in a merger proxy statement can safely continue to rely on the SEC's "no appraisal" policy, since the staff's position in the Gerstle brief may now be so widely known that a filing party would be charged with notice of the proposed exception to that policy. The facts in Gerstle demonstrate the need for a rule permitting the inclusion of appraisals in certain circumstances; therefore it

\footnotetext{
${ }^{47} 478$ F.2d at 1295 .

${ }^{48} I d$ at 1293.

${ }^{49} I d$ at 1294 (footnote omitted).

${ }^{50}$ Even for the future the Commission should proceed by a rule or a statement of policy that would receive wider public attention than an amicus brief in a private suit. We note with approval that this is what it has apparently determined to do with respect to any proposed rule changes to allow use of projections.
}

Id. at 1294 n.13. 
is now appropriate to provide certainty through the formulation of such a workable rule. ${ }^{51}$

The desirability of a reexamination of SEC appraisal policy is enhanced by the realization that, by denying to investors the benefit of reliable appraisal data in disclosure documents, the SEC may drive them to seek such information from less reliable sources not subject to regulation. The same objection voiced in support of a reexamination of SEC policy forbidding the use of projections in SEC documents ${ }^{52}$ - that the policy reduces the utility of SEC disclosure documents as aids to investment decisions, diverting this job to investment services ${ }^{53}$-may thus be voiced in support of lifting the broad ban on the use of appraisals. If appraisal data is sufficiently trustworthy to supply the investor with useful information for making investment decisions, without imposing undue administrative burdens on the SEC, no rational policy should require its exclusion.

\section{B. Changed Conditions in the Appraisal Profession}

As noted earlier in this Comment, ${ }^{54}$ the SEC's policy of excluding appraisal data from the narrative portion of filed documents was not intended to deprive investors of vital, needed information, but rather to protect individual shareholders and the public from fraud and misrepresentation. SEC policy is to a large extent a reaction to problems encountered in the attempted use of nonprofessional and grossly inaccurate appraisals. The causes of such abuse may be broken down into three general categories: problems of professionalism, of methods and of disclosure. ${ }^{55}$

${ }^{51}$ The Gerstle-type problem is a recurring one, calling in itself for the development of a more formal and definitive set of standards relating to the use of appraisals in SEC filings. In Becker v. Schenley Indus., Inc., [1972-1973 Transfer Binder] CCH FED. SEC. L. REP. I 93,669 (S.D.N.Y., Nov. 16, 1972), former minority shareholders of BHM Industries, Inc. allege that Schenley grossly undervalued the assets of BHM in a merger proxy statement. As in Gerstle the defendant has claimed that the SEC refused to permit the inclusion of appraisals in the proxy statement. At present, the case is in the discovery stage.

${ }^{52}$ The SEC is now preparing guidelines for the use of such projections in SEC filings. See SEC Securities Act Release No. 5362, SEC Exchange Act Release No. 9984 (Feb. 2, 1973), in [1972-1973 Transfer Binder] CCH FED. SEC. L. REP. ๆ 79,211.

${ }^{53}$ See, e.g., Mann, Prospectuses: Unreadable or Just Unread?-A Proposal to Reexamine Policies Against Permitting Projections, 40 Geo. WASH. L. REV. 222, 224-28 (1971); Reiling \& Burton, Financial Statements: Signposts as Well as Milestones, HARV. Bus. Rev, Nov.-Dec. 1972, at 45, 50-54. But see U.S. SECuRItIES \& EXChange CoMm'N, Disclosure to Investors: A Reappraisal of Federal Administrative Policies UNDER THE'33 AND'34 ACTS 95-96 (1969).

54 Notes 23-31 supra \& accompanying text.

55 In evaluating the ensuing discussion in the text, the reader should consider the relationship which has developed between the SEC and the accounting profession, and 


\section{The Problem of Professionalism}

One of the requirements which the SEC has consistently imposed when it has allowed appraisals to be referred to in a filed document ${ }^{56}$ is that the appraisals be made by a qualified expert. ${ }^{57}$ The Gerstle brief and statements in early opinions of the Commission indicate that certain factors are considered in evaluating the qualifications of an appraiser-whether he has experience and training in methods of evaluation, ${ }^{58}$ whether he adheres to fair and accurate standards of practice; $; 9$ and whether he exercises independent judgment. ${ }^{60}$ Thus, if the SEC is to

whether such a relationship could be developed between the SEC and the appraisal profession. While the Commission has the power to prescribe the form of presentation and the methods of preparation of data contained in disclosure documents, see, e.g., Securities Act of $1933 \S 19,15$ U.S.C. $\$ 77 \mathrm{~s}(1970)$, it has exercised this power sparingly. See L. RAPPAPORT, supra note 5, at 2.4-.6. Instead, it relies on "generally accepted accounting principles," as set by the American Institute of Certified Public Accountants (AICPA) as "the source for filling in the interstices in the Commission's rules." SEC Brief, supra note 25 , at 10 . The process of solving accounting problems as they relate to the SEC is a "joint or mutually cooperative effort" between the SEC and AICPA. And, because the SEC assists in the decisionmaking, it regards the opinions of the AICPA "as binding upon registrants filing financial statements." H. KELLOGG, supra note 5, I 1523.

Historically, the SEC has accepted the standards of the accounting profession, and when it has found fault with them the profession has responded by upgrading those standards. See Barr \& Koch, Accounting and the S.E.C., 28 GEO. WASH. L. REV. 176, 186-93 (1959). That the SEC depends to a great extent upon the AICPA to set standards can be attributed to the SEC's perception of the capabilities of the AICPA as a professional society and to the close working relationship between the Commission and the AICPA. The AICPA's formulation of "generally accepted accounting principles" lightens considerably the burden upon the SEC of ensuring uniformity in documents filed with it. Furthermore, though an accountant need not be certified to practice before the SEC, SEC Regulation S-X, Rule 2-01, 17 C.F.R. $§ 210.2-01$ (1973), the SEC may rely to some extent upon certification in practice as an indication that an accountant is qualified and independent. $C f$. L. RAPPAPORT, supra note 5, at 26.4-.8. Were the Commission not able to rely upon this designation, a tremendous administrative burden might be imposed upon it to license or otherwise ensure the competence and independence of those submitting financial statements for inclusion in SEC disclosure documents.

Thus, in the field of accounting, the general problems of professionalism, methods and disclosure have been solved for the SEC by the existence and competence of the AICPA. The SEC has failed to recognize any similar organization in the appraisal profession, and so the burden of setting appraisal standards has remained entirely on the Commission. Whether because of administrative convenience, lack of interest or both, the Commission has never shouldered that burden, and appraisals have generally been disallowed. The analysis in the text will suggest that existing professional appraisal societies are now prepared to assume the role in the appraisal field long played by the AICPA in the accounting area. Should this be true, the primary reasons for excluding appraisals from SEC documents-their perceived unreliability and a desire to avoid undue administrative burdens-should evaporate.

${ }^{56} \mathrm{E}$.g., an estimate of mineral resources owned by the registrant. See SEC Form S-1, Item 10, 1 CCH FED. SEC. L. REP. ๆ 7123.

${ }^{57}$ See, e.g., text accompanying note 45 supra.

${ }^{58}$ See, e.g., SEC Brief, supra note 25 , at 30 n. 32.

${ }^{59} C f$. Breeze Corps., Inc., 3 S.E.C. 709, 717 (1938); L. RAPPAPORT, supra note 5, at 3.30-.32.

${ }^{60}$ See Associated Gas \& Elec. Co., 11 S.E.C. 975, 1012 (1942); L. RAPPAPORT, supra note 5 , at 26.1-.55. 
accept any appraisal, some group-either the SEC or another body - must undertake the task of evaluating the qualifications and standards of practice of appraisers. A possible solution to this problem is reliance by the SEC on the senior membership designations of the existing professional appraisal societies, as a guarantee of the qualifications of those members.

The appraisal profession today embraces persons of widely disparate training and ability. To a large extent, the profession is unregulated. Some states have begun minimum licensing programs, ${ }^{61}$ while in others a person can practice as an appraiser without any formal or practical training. ${ }^{62}$ It was against this background that the SEC initially formulated its policy toward appraisals. Since World War II, however, significant numbers of appraisers have banded together into three major nationallybased professional appraisal societies which, at least in theory, set personal, procedural, and ethical standards for their members. These organizations are the American Society of Appraisers, the American Institute of Real Estate Appraisers and the Society of Real Estate Appraisers. The two latter organizations are concerned exclusively with real estate appraisal, while the American Society of Appraisers recognizes and is concerned with the appraisal of all classes of property. ${ }^{63}$ Each of these societies, through its national and local organizations, conducts courses and seminars for members, ${ }^{64}$ sets and enforces standards of ethical practice, ${ }^{65}$ and confers professional designations ${ }^{66}$ upon members who successfully meet specified standards of experi-

${ }^{61}$ Interview with Robert Truman, MAI, SREA, ASA, in Wilmington, Delaware, Oct. 25, 1972 [hereinafter cited as Truman Interview]. Massachusetts, for example, initiated a licensing system for appraisers of automobile damage on Apr. 1, 1972. The statute is exceedingly vague. The Commissioner of Insurance (the administrator of the program) is directed to issue a license "to any applicant he finds truthworthy [sic] and competent." MASS. GEN. LAwS ANN. ch. 175, \$113M (Supp. 1972).

${ }^{62}$ Truman Interview, supra note 61. California, New York and Pennsylvania are examples.

${ }^{6}$ See ASA Principles, supra note 12 , at 7.

${ }^{64}$ See Administrative Rule \#5-Educational Seminars, in AMERICAN SOCIETY OF APPRAISERS, Professional APPRAISAL SERVICES DIRECTORY - 1973, at 52; AMERICAN INSTITUTE OF REAL ESTATE APPRAISERS, CONTINUING EDUCATION CASE STUDY COURSES 1972; Regulation No. 1-Admissions to Membership, in SREA BY.LAWS \& STANDARDS, supra note 3 , at $14-15$.

${ }^{65}$ See American Institute of Real Estate ApPraisers, Regulation No. 10Code of Professional Ethics and STANDARdS of Professional Conduct (1973); ASA Principles, supra note 3, at 7-18; SREA BY-LAwS \& STANDARDS, supra note 12, at 10-12.

${ }^{66}$ The senior designations of the societies are as follows: American Institute of Real Estate Appraisers-MAI (Member Appraisal Institute), AMERICAN INSTITUTE OF REAL ESTATE APPRAISERS, BY-LAWS 1 (1972); American Society of Appraisers-ASA (Senior Member of American Society of Appraisers), American Society of Appraisers Constitution, in American Society of APPRaisers, Professional ApPraisal SERVices Directory1973, at 21-22; Society of Real Estate Appraisers - SREA (Senior Real Estate Analyst), International By-Laws, in SREA BY-LAWS \& STANDARDS, supra note 12, at 1-2. 
ence, ${ }^{67}$ character ${ }^{68}$ and education. ${ }^{69}$ Many sophisticated real estate investors will accept only appraisal reports prepared by persons holding the MAI or SREA designations. ${ }^{70}$ The senior designation of the American Society of Appraisers, while not so widely relied upon in the investment community, also appears to require considerable training for its attainment $t^{71}$ and is backed by a substantial code of ethics and professional standards. ${ }^{72}$

The sufficiency of the societies' membership standards and ethical codes will not be analyzed here. Their existence and the reliance placed upon them by private investors does suggest, however, that the SEC could, by requiring that all appraisal reports filed with it be prepared by independent appraisers holding the senior designation of a recognized professional appraisal society, be reasonably certain that such reports had been prepared by persons both skilled in appraisal practice and committed to standards of ethical conduct.

In addition to requiring that appraisal reports be prepared by senior members of a recognized appraisal society, the SEC might also require that such reports be submitted only by independent appraisers. An alternative approach, apparently favored by the Commission, calls only for full disclosure of any relationship between the appraiser and interested persons. ${ }^{73}$ Whether such disclosure would be a sufficient safeguard or

${ }^{67}$ The following number of years of appraisal experience are required before a person may be eligible for a senior designation: ASA -5 years, Administrative Rule \#3Procedure for Advancement to Senior Member, in AMERICAN SOCIETY OF APPRAISERS, Professional APPRAISAL SERVICES Directory-1973, at 50-51; MAI-5 years, AMERICAN INSTITUTE OF REAL ESTATE APPRAISERS, REGULATION NO. 1 ADMISSIONS AND MEMBERSHIP 14 (1973); SREA-8 years, Regulation No. 1-Admissions to Membership, in SREA BY.LAWS \& STANDARDS, supra note 12 , at 22.

${ }_{68}$ The admission procedures for each society include a character investigation. See, e.g., SREA BY-LAwS \& STANDARDS, supra note 12, at 13, 23. Furthermore, each society maintains disciplinary machinery whereby complaints of unethical conduct may be reviewed and appropriate sanctions applied where necessary. See, e.g., AMERICAN INSTITUTE of REAL Estate APPRAisers, Regulation No. 6-Ethics ProceduRES (1973).

${ }^{69}$ Each society requires that candidates for senior membership undergo a written examination, see, e.g., Administrative Rule \#3-Procedure for Advancement to Senior Member, in AMerican Society of APPRaISERS, Professional APPRAISAl SERvices Directory -1973 , at $50-51$, or complete certain courses administered by the society, see Regulation No. 1 -Admissions to Membership, in SREA BY-LAws \& STANDARDS, supra note 12, at 22. One society requires that candidates for its senior designation have graduated from an accredited 4-year college or the equivalent. See AMERICAN INSTITUTE Of REAL EsTATE APPRAISERS, REGULATION NO. 1-ADMISSIONS AND MEMBERSHIP 8 (1973).

${ }^{70}$ Truman Interview, supra note 61. See notes 66-69 supra.

${ }^{71}$ The technical requirements include 5 years full-time appraisal experience, submission of 2 sample appraisal reports, and successful completion of a written examination or the submission of an original technical paper suitable for publication. See Administrative Rule $\# 3$-Procedure for Advancement to Senior Member, in AMERICAN SOCIETY OF A PPRAISERS, PROFESSIONAL APPRAISAL SERVICES DIRECTORY - 1973, at 50.

${ }_{72}$ See ASA Principles, supra note 12, at 8-18.

${ }^{73}$ See SEC Brief, supra note 25 , at 30. 
whether a requirement of complete independence would be practical are questions which demand further consideration, as part of a more detailed study of SEC appraisal policy by SEC staff members in conjunction with qualified members of the appraisal profession.

\section{The Problem of Methods}

An early SEC opinion defined an appraisal as an expression "of judgment informed by knowledge and experience" that "purports to be more than an arbitrary determination of value. It seeks to attach value to objects as a consequence of method." ${ }^{.74}$ In other words, an appraisal must not only have been prepared by a qualified expert, it must have been prepared in accordance with acceptable appraisal methods.

The current absence of a single, uniform appraisal method deprives the SEC of a standard against which to test the accuracy and honesty of figures submitted for inclusion in filed documents $^{75}$ and may also prevent attainment of that degree of uniformity which is necessary to make such figures useful to investors seeking to compare alternative investment opportunities. A first-approximation solution to this problem is to restrict the use of appraisals in filed documents to those cases where a sale of assets is contemplated. ${ }^{76} \mathrm{~A}$ similar limitation was suggested in the Gerstle brief, which indicated that the only type of appraisal in a merger proxy statement that would not be misleading would be "one of the current liquidating value of assets."77 Such a limitation, however, does not describe with enough precision all cases in which the use of appraisal data should be prohibited due to a lack of confidence in the methodology underlying its preparation; and it may unnecessarily restrict uses of appraisals that should be encouraged due to the need of investors for such information.

The training programs of the various professional appraisal societies have resulted in the development of a large body of recognized appraisal methods. ${ }^{78}$ If such training material is made available to the SEC, it could be used to test the soundness of

${ }^{74}$ Haddam Distillers Corp., 1 S.E.C. 37, 42 (1934).

75"Accuracy" and "honesty" are used here to mean adherence to a recognized method of appraisal, purported to have been followed, with neither mistaken nor intentional misrepresentations. See Continental Distillers \& Importers Corp., 1 S.E.C. 54, 79 (1935); Haddam Distillers Corp., 1 S.E.C. 37, 42 (1934).

${ }^{76}$ This approach is supported as well by other considerations, and is adopted by this Comment. See notes $12-20$ supra \& accompanying text.

${ }^{77}$ SEC Brief, supra note 25 , at 29.

${ }^{78}$ Sinclair Interview, supra note 17 ; $c f$., e.g., AMERICAN INSTITUTE OF REAL ESTATE Appraisers, Continuing EduCation CaSe Study Courses 1972. 
methodology underlying appraisal data filed with the Commission. In order to assure uniformity and easier access to such standards, however, the professional appraisal societies should be encouraged to develop a single set of accepted appraisal principles. Were these to conflict with SEC needs, rules comparable to those found in SEC Regulation S-X $\mathrm{X}^{79}$ could be issued to indicate that certain procedures are not acceptable for the preparation of filed reports. 80

The cooperation or interplay between the SEC and the appraisal profession that the above discussion envisions could provide a basis for expanding the use of appraisals into other areas where such data would be particularly helpful to the investor. Rather than relying on the widely criticized case-bycase method of dealing with the use of appraisals, ${ }^{81}$ the SEC and the profession could determine in advance those areas where appraisals would be required or allowed and could define the methods of appraisal that would be acceptable in given circumstances.

\section{The Problem of Disclosure}

Assuming that the problems of professional qualifications and appraisal methodology can be solved, thought must be given to the amount of appraisal information to be included in filed documents, and the form such disclosure should take, in order to make the stated appraisal result not misleading. Ideally, of course, the investor should read the entire appraisal report. However, given the practical difficulties inherent in printing an entire report and including it in a filed document, and the fact that an investor would not be likely to read such a report thoroughly were it included, lesser standards of disclosure should be developed.

In the Gerstle brief, the following information, to be set forth in a summary statement in the disclosure document, was considered adequate: "(a) the factual basis for the appraisal, (b) the relationship-if any-between the appraiser and interested persons and (c) the terms of the appraiser's engagement, including the instructions given to the appraiser as to the purpose and methods of appraising."82 Other items which might be required include the date of the appraisal and a summary of the appraiser's experience. Again, consultation with quaiified

${ }^{79} 17$ C.F.R. $\$ \$ 210.1-01$ to $.12-43$ (1973).

${ }^{80}$ For a discussion of the SEC's relationship to the accounting profession, see note 55 supra.

${ }^{81}$ See, e.g., Manne, supra note 5, at 327-31.

${ }^{82}$ SEC Brief, supra note 25 , at 30. 
members of the appraisal profession would assist the SEC in the preparation of formal rules prescribing the content and form of such a summary statement. Once such a rule has been promulgated, the professional societies could be called upon to offer to their members formal instruction relating to the proper drafting of such statements.

\section{The Need for Dialogue}

The discussion of these problem areas suggests that by opening a dialogue with qualified representatives of the appraisal profession, the SEC could establish a working relationship with appraisers out of which could come solutions to these and other problems arising from the use of appraisals in SEC documents. By relying on professional appraisal societies to police standards and develop accepted appraisal principles, the SEC need only formulate specific regulations dealing with its particular appraisal problems and so can avoid overwhelming administrative burdens.

Many of the suggestions made above are necessarily openended, because the SEC and the appraisal profession have not yet made any cooperative effort to provide standards by which reliable, helpful appraisal information could be made available to investors through SEC filings. An advisory committee consisting of appraisers, attorneys, accountants and SEC staff members is needed to explore the problems raised here, and to develop a set of rules to replace the discredited policy of excluding all appraisals from SEC documents.

\section{AN AGENDA FOR REFORM}

The advisory committee just proposed would be equipped to do much more than solve the Gerstle problem. This body should undertake a full analysis of those areas in which there is a need for appraisal data, and formulate rules to govern the use of appraisals in any and all appropriate SEC documents. This section will attempt to define the areas where the inclusion of appraisal data in the narrative portion of filed documents would contribute significantly to investor knowledge and, where possible, will set forth proposed rules to govern their inclusion.

\section{A. Proxy Statements}

The SEC staff in the Gerstle brief called for the disclosure of existing appraisal data, prepared by a qualified expert and 
sufficiently based on fact, when a merger proxy statement "reflects assets at an amount that is substantially lower than their current liquidating value, and liquidation of those assets is intended or can reasonably be anticipated ...."83 The brief states that "liquidation may reasonably be anticipated" when there exists "a fairly ready market for the various assets of the corporation." 84 Other circumstances which might constitute "reasonable anticipation" are not specified.

Both reported cases in which shareholders have challenged a failure to include appraisal values in a merger proxy statement have involved situations in which the surviving corporation controlled the disappearing corporation before the merger. ${ }^{85}$ This suggests that the SEC's policy statements in the Gerstle brief ought to be limited to those mergers which do not involve arms-length dealing. Where merger terms are the product of arms-length negotiation, that fact should be sufficient to ensure that the terms are fair to the stockholders of both corporations. Requiring an appraisal of the assets of either merging partner in such a context would simply be second-guessing management, whose negotiations encompass many diverse factors, and might in fact deprive an astute management group of the benefit of its bargain by emphasizing to the other party the relative asset values of the two corporations. ${ }^{86}$ Furthermore, except in a parent-subsidiary context, it may be both impractical and inequitable to place the burden upon the acquiring corporation, as was done in Gerstle, of making disclosures concerning appraised values of property held by the other corporation. ${ }^{87}$

Even if the Gerstle rules governing the disclosure of existing

${ }^{83}$ Id. 19.

${ }^{84}$ Id. 20.

This particular indicator of when liquidation may be reasonably anticipated was apparently designed to cover cases such as Speed v. Transamerica Corp., 99 F. Supp. 808 (D. Del. 1951), additional opinion, 135 F. Supp. 176 (D. Del. 195.5), modified, 235 F.2d 369 (3d Cir. 1956), in which insiders purchased stock from other shareholders without disclosing that the corporation's principal asset, an inventory of tobacco, had appreciated greatly above its book value. See SEC Brief, supra note 25, at 26 n.28.

8. In Gerstle, Gamble-Skogmo owned “50.1\% of General's stock." 298 F. Supp. at 73. In the only other reported case involving a claim similiar to that of Gerstle, Becker v. Schenley Indus., Inc., [1972-1973 Transfer Binder] CCH FED. SEC. L. REP. If 93,669, at 92,986 (S.D.N.Y., Nov. 16, 1972), Schenley owned $52.7 \%$ of BHM Industries, Inc., the disappearing corporation.

${ }^{86}$ Cf. Kohn v. American Metal Climax, Inc., 458 F.2d 25.5, 265 (3d Cir.), cert denied, 409 U.S. 874 (1972). In that case the court, in its evaluation of a proxy statement dealing with a proposed amalgamation of assets of two mining companies, held that the omission of estimates of the value of the assets of one of the companies was not material. The court noted that the estimates had been advanced during the negotiations as part of the parties' bargaining strategy.

${ }^{87}$ See Mutual Shares Corp. v. Genesco, Inc., 266 F. Supp. 130, 132 n.2 (S.D.N.Y.), aff' in part \& rev'd in part, 384 F.2d 540 (2d Cir. 1967) ("When defendants made their public offer for tenders... they were 'outsiders' and hence were under no duty to disclose any knowledge they might have had as to the true value of Kress' real estate."). 
appraisal data are limited to the parent-subsidiary merger context, they raise a number of problems. First, by limiting the requirement of disclosure to existing appraisals, the Gerstle rule would permit a controlling company which intended to liquidate assets of the controlled company after a merger to avoid disclosure of the current value of such assets simply by failing to prepare or order a formal appraisal until after the merger or acquisition had been completed. This could encourage the use of informal, in-house appraisals in order to avoid disclosure. ${ }^{88}$ Second, by requiring that appraisal data be disclosed only in those situations where it reflects asset values substantially higher than those shown in the balance sheet accompanying a proxy statement, the Gerstle rules may permit a company, through its interpretation of the term "substantially," to deprive investors of information which would allow them to determine independently whether historical cost is an accurate reflection of asset values. Finally, the requirement that the controlling corporation have an intent to liquidate the assets of the controlled corporation, or that such liquidation be "reasonably anticipated," is subject to criticism on the ground that it is too subjective a standard to be easily and fairly enforced.

Appraisal data should not, however, be required in all cases; liquidating values are irrelevant where a subsidiary will continue to be operated as a going concern, ${ }^{89}$ and a parent company should not be required to incur the cost of an independent appraisal where a sale of the assets of the controlled corporation is so unlikely as to be immaterial to the selling shareholders' decisions. With these considerations in mind, the following addition to Exchange Act Schedule $14 \mathrm{~A},{ }^{90}$ Item 14 is suggested to govern disclosures of appraisal values in merger proxy statements:

(d) If the issuer is a subsidiary of any person described in (b) [i.e. a merger participant]; and if such person intends to sell any part of the assets of the issuer within one year after the completion of the [merger]

${ }^{88}$ A strict interpretation of the "qualified expert" requirement set forth in the Gerstle brief might well have resulted in a finding by the district court that the appraisals held by Skogmo, which were prepared by officers of General, see 298 F. Supp. at 76, were not the type of appraisal contemplated by the SEC staff.

${ }^{89}$ See SEC Brief, supra note 25, at 19-20. But see Manne, supra note 5, at 325-26.

Professor Manne suggests that all merger situations logically require liquidation accounting because, if the merger is approved, the corporation will cease to exist as a separate entity; knowledge of liquidation value is needed to enable the shareholders to determine whether liquidation would be preferable to merger. Id. The flaw in this argument is that a shareholder's choice in voting upon a merger proposal is not to merge or to liquidate, but rather to merge or to continue holding stock in a going corporation. This decision does not necessarily require disclosure of liquidating values.

${ }^{90} 17$ C.F.R. $\$ 240.14 a-101$ (1973). 
plan, or there is a reasonable probability of such a sale; and the proceeds of such a sale or sales are reasonably anticipated to exceed 15 percent of the net assets of the issuer as reported in its balance sheet filed pursuant to Item 15; then state the current liquidating value of such assets. Such value shall be determined by an independent appraisal.

This proposed rule, while retaining a subjective standard of intent, permits a parent corporation to liquidate a former subsidiary's assets at any time more than one year after the merger ${ }^{91}$ The fifteen percent threshold is designed to eliminate the need for an appraisal where a sale of assets would not be material.

The most significant difference between this proposed rule and the rule developed in the Gerstlebrief ${ }^{92}$ is that it requires that appraisal data be developed if none exists, rather than only requiring disclosure of existing asset value data. This recognizes that, when liquidation or a sale of assets of a controlled subsidiary is a serious possibility, the management of a parent corporation has a positive duty to give minority shareholders of the subsidiary sufficient information to enable them to make an intelligent evaluation of the parent's action. ${ }^{93}$ Furthermore, the proposed rule does not allow the management of the parent corporation to keep appraisal data from minority shareholders of the subsidiary on the subjective ground that it does not reflect assets at an amount substantially higher than book value. ${ }^{94}$

${ }^{91}$ When assets are held for a year following the merger, the likelihood that the surviving corporation entered the transaction with the intent to liquidate its subsidiary is substantially reduced; at the same time there is a greater probability of changed conditions making sale desirable. In order to prevent asset sales from becoming overly complicated by inquiry into intentions at the time of the merger, the suggested rule converts the probability of no intent to sell into a presumption.

${ }^{92}$ See SEC Brief, supra note 25 , at 19.

${ }^{93} \mathrm{Cf}$. Schneider, Nits, Grits, and Soft Information in SEC Filings, 121 U. PA. L. Rev. 254,283 (1972) (suggesting that in many cases disclosure of current values should be mandatory).

${ }^{94}$ Proxy statements in situations other than the parent-subsidiary merger may be found, after appropriate study, to require use of appraisal data. In general, appraisals would be useful whenever liquidation is forseeable and the danger of insider abuse of the rights of minority shareholders exists.

An example of such a case is SEC v. Florida East Coast Railway, complaint summarized in 187 BNA SEC. REG. \& L. REP. A-2 (D.D.C., filed Jan. 24, 1973). The SEC's complaint in that case alleges, inter alia, that the railroad violated rule $14 \mathrm{a}-9$ by filing with the Commission a proxy statement, relating to a proposed recapitalization, that was false and misleading in that it failed to disclose the fair value of the company's assets, as well as other information relating to a property that was to be condemned at a price substantially exceeding its book value.

Appraisals also ought to be employed in proxy solicitations for shareholder approval of a statutory liquidation, and in cases where shareholder approval is required for the sale of assets. See Swanson v. American Consumer Indus., Inc., 415 F.2d 1326, 1330-32 (7th Cir. 1969) (proxy statement concerned the sale of a subsidiary's assets to parent 


\section{B. Registration Statements Under the 1933 Act}

A general reexamination of SEC appraisal policy should also include a determination of when, if ever, current liquidating values of assets should be disclosed in 1933 Act registration statements. ${ }^{95}$ Presumably, an investor's primary interest in examining a filed document is to determine the future earning capacity of the issuer. ${ }^{96}$ In most cases, historical cost and income figures will provide a reasonable guide to the earning capacity of a going concern. However, in the case of a new issue, there are certain circumstances in which strict adherence to historical cost may be misleading and supplementary appraisal data may be called for.

Consider, for example, the situation of a company that has a significant ratio of fixed assets to total assets, the fixed assets having a current value substantially higher than their original cost. "[I] $f$ there is an existing mortgage on the assets, ... it must be recorded on the balance sheet as a liability even though it may exceed the cost of the asset." 97 Thus, despite the fact that appreciation of fixed assets results in an increase in the company's ability to attract credit, such appreciation may not be reflected in a registration statement.

The following hypothetical suggests another circumstance in which a prohibition against the inclusion of appraised values may mislead investors. Suppose that company $A$, involved in real estate development, acquired land in a resort area in 1960 at a cost of $\$ 500,000$. In 1970 , that same undeveloped land had an appraised value of $\$ 1,000,000$, reflecting a general increase in the market value of surrounding property. Company $B$, also engaged in real estate development, acquired a neighboring tract of land in the same resort area in 1970 at a cost of $\$ 500,000$. In

corporation; complaint, alleging violation of rule $10 \mathrm{~b}-5$ for failure to state, inter-alia, appraised value of assets to be sold, stated valid cause of action). Appropriate rules should be formulated to alert filing companies to the need for appraisals in these contexts, in addition to the formulation of the more general rules dealing with appraisal methods and standards suggested at text accompanying notes 54-82 supra.

By analogy, disclosure of appraisals might ultimately be called for in situations not involving proxy statements. The most celebrated example illustrating the need for such disclosure is Speed v. Transamerica Corp., 99 F. Supp. 808 (D. Del. 1951), additional opinion, 135 F. Supp. 176 (1955), modified, 235 F. 2d 369 (3d Cir. 1956). In that case, insiders purchased stock without disclosing that the liquidating value of the corporation's tobacco inventory was much higher than its book value. The SEC contended successfully that under rule $10 \mathrm{~b}-5$, the appreciation of corporate assets must be disclosed when the corporation or its insiders seek to purchase its stock.

${ }^{95}$ Registration statements are required by Securities Act of $1933 \S \S 6,7,15$ U.S.C. $\$ \S 77 f, 77 \mathrm{~g}(1970)$.

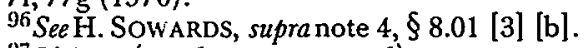

${ }^{97}$ Id. 8-23 (emphasis in original). 
1971, both companies decide to go public. Neither has an established record of earnings; yet $A$ should be able, all other factors being equal, to sell its stock for twice as much as $B$. But if both are required to show their land acquisitions at historical cost, and are prohibited from disclosing appraised values, the registration statements will appear to offer the investor identical opportunities for investment return. ${ }^{98}$

Both hypotheticals illustrate how a prohibition against disclosure, in the narrative portion of a registration statement, of appreciated asset values in an inflationary asset market can distort the quality of information available to potential investors. ${ }^{99}$ This type of problem may be unique to companies whose future earnings are to be derived substantially from the sale or lease of fixed assets rather than from the production of goods or services with those assets. In one sense, a company engaged primarily in the sale of nondepreciating assets is constantly undergoing a form of liquidation which calls for investor focus upon liquidating as well as going concern values. With these considerations in mind, the following added instruction to SEC Form S-1, Item $10^{100}$ is proposed:

If more than 15 percent of the issuer's assets consists of fixed assets or real property, held primarily for lease or sale, the current liquidating value of such assets, based upon a qualified independent appraisal, must be disclosed.

This proposed rule should result in the disclosure of materially appreciated asset values and should also insure that material deteriorations in asset value below historical cost will be indicated in the registration statement.

\section{Other Disclosure Documents}

One factor which justifies the mandatory inclusion of appraisal data in a registration statement or a merger proxy

${ }^{98}$ In such a situation the physical descriptions of the properties are likely to differ considerably, but this would not necessarily indicate to the investor a large difference in value.

${ }^{99}$ It is not entirely clear that such information is prohibited. One article draws from Study GROUP ON BUSINESS INCOME, REPORT ON CHANGING CONCEPTS OF BusINESS INCOME (1952) the suggestion that "financial statements which reflect the effect of changes in purchasing power be included as supplemental material in stockholder reports and other reports issued by a company." Barr \& Koch, Accounting and the S.E.C., 28 GEO. WASH. L. Rev. 176, 182 (1959). Since the Commission staff did not object to this proposal, those authors infer,

it appears that while the Commission has not amended its rules to require the filing of such statements as supplementary material it probably would not object to the inclusion of such statements as supplemental material in a filing with the Commission.

Id.

${ }^{100} 1$ CCH FED. SEC. L. REP. ๆ 7123. 
statement is that these documents are filed in connection with rather significant corporate events, where the cost of an independent appraisal of assets is acceptable in view of the magnitude of the investment decision involved. Were the SEC to require appraisals in periodic reports filed pursuant to the 1934 Act, ${ }^{101}$ the cost of preparation and the administrative burden of reviewing them would seem prohibitive in view of the relative unimportance of the documents. However, in the case of companies engaged in the continuous liquidation of real estate, the value to investors of disclosure, in reports to shareholders, of material changes in asset values might outweigh the costs when property turnover is not so rapid that asset appreciation is substantially reflected in the company's income statements. Some thought should be given to encouraging the optional inclusion of current asset values, along with historical cost, in such situations.

Assuming that such disclosures might be desirable, the question remains what form they should take. The burden of preparing frequent formal appraisals is probably too heavy for most companies; while a simple statement that management believes that stated historical values are too high or too low would be of little use to the investor. Disclosure of recent sale prices of comparable assets or of the security value placed on such assets by independent financial institutions would be simple, but these figures could be misinterpreted by investors not familiar with appraisal technique. The optimal solution may rest in encouraging companies to disclose management's opinion, clearly delimited as such, as to the approximate percentage of increase or decrease in the value of assets since their acquisition, and the reasons therefor. Much more thought is needed in this troublesome area before a specific rule can be proposed.

\section{CONCLUSIONS}

When the sale or other disposition of a material part of a corporation's assets is intended or a sale or other disposition may be reasonably anticipated as a result of the company's operations, historical cost accounting combined with current earnings data may mislead an investor called upon to make an investment decision, or may not supply him with adequate information on which to base an informed decision. In such situations, an accurate appraisal of the liquidating value of the assets would be

${ }^{101}$ Periodic reports are required by Securities Exchange Act of $1934 \S 13,15$ U.S.C. $\S 78 \mathrm{~m}(1970)$. 
useful to the investor. The primary regulatory task posed by this situation is to pinpoint in advance those circumstances in which appraisal value is less likely than historical cost to be misleading as an estimate of the actual amount to be received on liquidation.

Relevant factors in determining whether or not an appraisal should be required or permitted to be filed include the qualifications of the appraisal profession, and of individual appraisers, to perform a competent appraisal of the assets involved; the cost to the filing company of providing reliable appraisal data; the administrative burden imposed upon the SEC; and the risks assumed by the public. While the significance of these factors may vary with the type of document filed, situations do exist in which the risks and costs involved in the use of appraisals are outweighed by investors' need for more useful data than historical cost to reflect the current liquidating value of assets. These situations include mergers between parent and subsidiary corporations, when the parent intends to sell a substantial portion of the subsidiary's assets; and the registration under the 1933 Act of a corporation which holds a substantial amount of real property for the purpose of lease or sale.

Further study, including the commencement of a dialogue between the SEC staff and members of the appraisal profession, is necessary to discover the extent to which the appraisal profession can guarantee the reliability of appraisal data included in filed documents, reducing the social and administrative costs of its use. An advisory committee must be formed to propose a basic framework of rules to govern the use of appraisals, designed to protect the invistor from overreaching by corporate insiders and majority stockholders, to provide him with an increased amount of reliable data, and to rescue filing corporations from their present precarious position between the SEC's general policy of full disclosure and its restrictive attitude toward the use of appraisals. 